\title{
Front Matter: Volume 6985
}

, "Front Matter: Volume 6985," Proc. SPIE 6985, Fundamentals of Laser Assisted Micro- and Nanotechnologies, 698501 (24 January 2008); doi: 10.1117/12.790445

SDIE Event: Fundamentals of Laser Assisted Micro- and Nanotechnologies, 2007, St. Petersburg, Russian Federation 


\title{
PROCEEDINGS OF SPIE
}

\section{Fundamentals of Laser Assisted Micro- and Nanotechnologies}

\author{
Vadim P. Veiko \\ Editor
}

\section{5-28 June 2007 \\ St. Petersburg, Russia}

\section{Organized by}

St. Petersburg State University of Information Technologies, Mechanics and Optics (Russia) General Physics Institute of Russian Academy of Sciences

S.I. Vavilov State Optical Institute (Russia)

In cooperation with

SPIE Russian Chapter

Laser Association (Russia)

D.S. Rozhdestvensky Russian Optical Society (Russia)

\section{Sponsored by}

Russian Federation Ministry of Education and Science

Russian Foundation for Basic Research

St. Petersburg State University of Information Technologies, Mechanics and Optics (Russia)

General Physics Institute of Russian Academy of Sciences

Ecole Nationale d'Ingenieurs de Saint-Etienne (France)

EOARD-European Office of Aerospace Research and Development

Leading Scientific School Fundamentals of Laser Microtechnologies (Russia)

Leading Scientific School of Russian Federation Photophysics of Nanoscale Surface Structures

State Museum Preserve Tsarskoye Selo (Russia)

Published by

SPIE

Volume 6985 
The papers included in this volume were part of the technical conference cited on the cover and title page. Papers were selected and subject to review by the editors and conference program committee. Some conference presentations may not be available for publication. The papers published in these proceedings reflect the work and thoughts of the authors and are published herein as submitted. The publisher is not responsible for the validity of the information or for any outcomes resulting from reliance thereon.

Please use the following format to cite material from this book:

Author(s), "Title of Paper," in Fundamentals of Laser Assisted Micro- and Nanotechnologies, edited by Vadim P. Veiko, Proceedings of SPIE Vol. 6985 (SPIE, Bellingham, WA, 2008) Article CID Number.

ISSN 0277-786X

ISBN 9780819471833

Published by

SPIE

P.O. Box 10, Bellingham, Washington 98227-0010 USA

Telephone +1 3606763290 (Pacific Time) · Fax +1 3606471445

SPIE.org

Copyright (C 2008, Society of Photo-Optical Instrumentation Engineers

Copying of material in this book for internal or personal use, or for the internal or personal use of specific clients, beyond the fair use provisions granted by the U.S. Copyright Law is authorized by SPIE subject to payment of copying fees. The Transactional Reporting Service base fee for this volume is $\$ 18.00$ per article (or portion thereof), which should be paid directly to the Copyright Clearance Center (CCC), 222 Rosewood Drive, Danvers, MA 01923. Payment may also be made electronically through CCC Online at copyright.com. Other copying for republication, resale, advertising or promotion, or any form of systematic or multiple reproduction of any material in this book is prohibited except with permission in writing from the publisher. The CCC fee code is $0277-786 \mathrm{X} / 08 / \$ 18.00$.

Printed in the United States of America.

Publication of record for individual papers is online in the SPIE Digital Library.

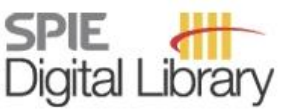

SPIEDigitallibrary.org

Paper Numbering: Proceedings of SPIE follow an e-First publication model, with papers published first online and then in print and on CD-ROM. Papers are published as they are submitted and meet publication criteria. A unique, consistent, permanent citation identifier (CID) number is assigned to each article at the time of the first publication. Utilization of CIDs allows articles to be fully citable as soon they are published online, and connects the same identifier to all online, print, and electronic versions of the publication. SPIE uses a six-digit CID article numbering system in which:

- The first four digits correspond to the SPIE volume number.

- The last two digits indicate publication order within the volume using a Base 36 numbering system employing both numerals and letters. These two-number sets start with 00, 01, 02, 03, 04, 05, $06,07,08,09,0 A, 0 B \ldots 0 Z$, followed by $10-12,20-2 Z$, etc.

The CID number appears on each page of the manuscript. The complete citation is used on the first page, and an abbreviated version on subsequent pages. Numbers in the index correspond to the last two digits of the six-digit CID number. 


\title{
Contents
}

\author{
vii Conference Committees \\ ix Introduction
}

SECTION 1 LASER-ASSISTED DIAGNOSTICS AND SPECTROSCOPY

698502 The role of plasmon-polaritons and waveguide modes in surface modification of semiconductors by ultrashort laser pulses [6985-01]

G. A. Martsinovsky, G. D. Shandybina, D. S. Smirnov, St. Petersburg State Univ. of Information Technologies, Mechanics and Optics (Russia); S. V. Zabotnov, L. A. Golovan, V. Yu. Timoshenko, P. K. Kashkarov, M.V. Lomonosov Moscow State Univ. (Russia)

698503 Three-dimensional nanomodification with ultrafast pulse laser [6985-02]

Y. Shimotsuma, M. Sakakura, M. Shimizu, K. Miura, Kyoto Univ. (Japan); P. G. Kazansky, Univ. of Southampton (United Kingdom); K. Hirao, Kyoto Univ. (Japan)

698504 Possibility of control of propagation regime in medium with cubic nonlinearity for chirped femtosecond pulse under the temporal dispersion of nonlinear response [6985-03]

V. A. Trofimov, A. G. Volkov, Lomonosov Moscow State Univ. (Russia)

698505 Selective laser melting process monitoring with high speed infra-red camera and pyrometer [6985-04]

F. Bayle, M. Doubenskaia, Ecole Nationale d'Ingénieurs de Saint-Etienne (France)

698506 Optical properties of the chalcogenide films for interference coatings in IR spectral range [6985-05]

E. N. Kotlikov, V. N. Prokashev, St. Petersburg State Univ. of Aerospace Instrumentation

(Russia); A. N. Tropin, Scientific-Research Institute, Giricond (Russia)

698507 Laser technological system for precision 3D material treatment and inspection [6985-06]

A. G. Verkhogliad, Technological Design Institute of Scientific Instrument Engineering (Russia)

698508 A study of thermally stimulated reversible rearrangement of the structure and optical parameters of molecular layers and solutions: IR image visualization based on the stereoisomerization of molecular systems [6985-07]

L. N. Asnis, E. N. Kaliteevskaya, V. P. Krutyakova, T. K. Razumova, St. Petersburg State Univ. of Information Technologies, Mechanics and Optics (Russia); A. N. Tarnovskii, Bowling Green State Univ. (USA); A. S. Tibilov, S. A. Chizhov, S.I. Vavilov State Optical Institute (Russia)

\section{SECTION $2 \quad$ LASER TECHNOLOGY IN MATERIAL SCIENCES}

698509 Dynamics of bulk modification inside glass by femtosecond laser [6985-08]

M. Sakakura, M. Terazima, K. Miura, Y. Shimotsuma, K. Hirao, Kyoto Univ. (Japan) 
$69850 \mathrm{~A}$ 3D transient model for $\mathrm{CO}_{2}$ laser hardening [6985-09]

G. Tani, DIEM, Univ. of Bologna (Italy); L. Orazi, DISMIS, Univ. of Modena and Reggio Emilia (Italy); A. Fortunato, G. Campana, A. Ascari, DIEM, Univ. of Bologna (Italy)

6985 OB High rate ablative formation of ultra-deep channels by self-adaptive Nd:YAG laser with dynamically adjustable passive Q-switch [6985-10]

T. T. Basiev, A.M. Prokhorov General Physics Institute (Russia); A. V. Fedin, V.A. Degtyarev Kovrov State Technological Academy (Russia); S. V. Garnov, A.M. Prokhorov General Physics Institute (Russia); A. V. Gavrilov, V.A. Degtyarev Kovrov State Technological Academy (Russia); S. M. Klimentov, P. A. Pivovarov, A.M. Prokhorov General Physics Institute (Russia); S. N. Smetanin, S. A. Solokhin, V.A. Degtyarev Kovrov State Technological Academy (Russia)

6985 OC Waves of optical bleaching caused by continuously operated Nd:YAG laser radiation in glass-ceramics [6985-11]

V. Veiko, E. Shakhno, E. Yakovlev, B. Novikov, St. Petersburg State Univ. of Information Technologies, Mechanics and Optics (Russia)

6985 OD Laser cleaning of metal surfaces: physical processes and applications [6985-12] V. P. Veiko, T. Ju. Mutin, V. N. Smirnov, E. A. Shakhno, St. Petersburg State Univ. of Information Technologies, Mechanics and Optics (Russia); S. A. Batishche, B.I. Stepanov Physical Institute (Belarus)

6985 OE Crystallization phenomenon in different glass-ceramic and glass materials under $\mathrm{CO}_{2}$ laser action [6985-13]

V. P. Veiko, A. I. Ignatyev, N. V. Nikonorov, E. B. Yakovlev, D. V. Orlov, St. Petersburg State Univ. of Information Technologies, Mechanics and Optics (Russia)

6985 OF Laser deposition of SmCo thin film on steel substrate [6985-14] L. Allocca, CNR, Istituto Motori (Italy); U. Gambardella, CNR-INFM, Lab. Regionale Supermat (Italy); A. Morone, CNR, Istituto di Metodologie Inorganiche e dei Plasmi-Unità Distaccata di Potenza (Italy); M. Valentino, CNR-INFM Coherentia (Italy) and Univ. di Napoli Federico II Piazzale V. Tecchio (Italy)

698506 Destruction of metals at solid state induced by laser [6985-15]

Yu. Chivel, Institute of Molecular and Atomic Physics (Belarus); M. Petrushina, United Institute of Informatics Problems (Belarus)

$6985 \mathrm{OH} \quad$ Nanoparticle thin films deposited by MAPLE for sensor applications [6985-16]

A. P. Caricato, Univ. del Salento (Italy); S. Capone, M. Epifani, M. Lomascolo, Istituto per la Microelettronica ed i Microsistemi, CNR (Italy); A. Luches, M. Martino, F. Romano, Univ. del Salento (Italy); R. Rella, P. Siciliano, J. Spadavecchia, A. Taurino, Istituto per la Microelettronica ed i Microsistemi, CNR (Italy); T. Tunno, D. Valerini, Univ. del Salento (Italy)

69850 Ol Laser-assisted micro sheet forming [6985-17]

J. Holtkamp, A. Gillner, Fraunhofer Institute for Laser Technology (Germany)

6985 0J Deposition of films and layers for sensors with PLD and LIFT method [6985-18]

S. A. Mulenko, Y. V. Kudryavtsev, N. T. Gorbachuk, Institute for Metal Physics (Ukraine);

A. Luches, A. P. Caricato, Univ. of Salento (Italy); V. P. Veiko, V. A. Chuiko, A. A. Petrov,

St. Petersburg State Univ. of Information Technologies, Mechanics and Optics (Russia) 
6985 OK Features of kinetics of clusters formation under intensive evaporation of small solid particles by short laser pulses [6985-19]

G. A. Lukyanov, O. I. Simakova, N. Yu. Bykov, Ctr. for Advanced Studies (Russia)

$6985 \mathrm{OL}$ Modeling of metal nanoclusters formation, growth, and deposition on a surface under pulsed laser ablation in a vacuum [6985-20]

G. A. Lukyanov, N. Yu. Bykov, L. Yu. Nikolaeva, St. Petersburg State Polytechnical Univ. (Russia)

6985 OM Precision laser system based on complementary scanning principle for dielectric materials microprocessing [6985-21]

N. Goloshevsky, A. Aleshin, S. Baev, V. Bessmeltsev, K. Smirnov, M. Maksimov, M. Mikhailov, Institute of Automation and Electrometry (Russia)

6985 ON Diffractive model of radiation scattering by a rough surface: dependence of a spatial frequency spectrum on size of roughness [6985-22]

V.I. Bronnikov, Joint Co. ISC Sun Energies (Russia)

$698500 \quad$ Using of middle IR lasers for guided termocleavage of glass [6985-23]

V. K. Sysoev, Lavochkin Association (Russia); Yu. N. Bulkin, RFNC-VNIIEF (Russia);

P. A. Vyatlev, Lavochkin Association (Russia); A. N. Soldatov, GY (Russia)

6985 OP Laser-induced plume expansion from a silicon wafer in a wide range of ambient gas pressure [6985-24]

A. N. Volkov, National Univ. of Ireland, Galway (Ireland); G. A. Lukianov, St. Petersburg Polytechnical Univ. (Russia); G. M. O'Connor, National Univ. of Ireland, Galway (Ireland)

$6985 \mathrm{OQ} \quad$ Laser micro sintering of $\mathrm{SiO}_{2}$ with an NIR-laser [6985-25]

A. Streek, P. Regenfuß, T. Süß, R. Ebert, H. Exner, Hochschule Mittweida (Germany)

SECTION 3 ULTRA SHORT LASER PULSES: INTERACTION WITH A MATTER AND APPLICATION IN MICROAND NANOTECHNOLOGIES

6985 OR Dynamics of shock waves generated in liquids by high-energy KrF laser [6985-27]

V. Zvorykin, P.N. Lebedev Physical Institute (Russia); L. Berthe, Lab. pour l'Application des Lasers de Puissance, CNRS (France); M. Boustie, Lab. de Combustion et de Détonique, CNRS, Univ. de Poitiers-ENSMA (France); A. Levchenko, N. Ustinovskii, P.N. Lebedev Physical Institute (Russia)

6985 OT High-power lasers at RFNC-VNIIEF [6985-29]

S. G. Garanin, Russian Federal Nuclear Ctr., VNIIEF (Russia)

Author Index 
Downloaded From: https://www.spiedigitallibrary.org/conference-proceedings-of-spie on 26 Apr 2023

Terms of Use: https://www.spiedigitallibrary.org/terms-of-use 


\title{
Conference Committees
}

\author{
Conference Honorary Chairs \\ Vladimir N. Vasiliev, ITMO (Russia) \\ Ivan A. Shcherbakov, GPI RAS (Russia) \\ Conference Chairs \\ Vadim P. Veiko, ITMO (Russia) \\ Vitaly I. Konov, GPI RAS (Russia) \\ Program Committee Cochairs \\ S. Garnov, GPI RAS (Russia) \\ M. J. Soileau, CREOL (USA) \\ K. Sugioka, RIKEN (Japan) \\ T. Szörenyi, Szeged University (Hungary) \\ V. P. Veiko, ITMO (Russia) \\ Scientific Secretary \\ Vadim A. Parfenov, ITMO (Russia) \\ Organizing Committee Cochairs
A. A. Allas, ITMO (Russia)
V. L. Komolov, ITMO (Russia)
E. B. Yakovlev, ITMO (Russia)
E. Yu. Yutanova, ITMO (Russia) 
Downloaded From: https://www.spiedigitallibrary.org/conference-proceedings-of-spie on 26 Apr 2023

Terms of Use: https://www.spiedigitallibrary.org/terms-of-use 


\section{Introduction}

To the memory of A. M. Bonch-Bruevich, A. Guenther, and M. N. Libenson, founders of Russian and international conferences on non-resonant laser-matter interaction.

This volume presents selected papers of the International Conference on Fundamentals of Laser-Assisted Micro- and Nanotechnologies (FLAMN-07).

This conference continues in the new format of other well-known traditional symposiums such as Intensive Laser Actions and Technological Applications (ILATA), consisting of Laser-Assisted Microtechnologies (LAMN) and Laser-Matter Interaction (LMI) conferences which were previously organized in former Leningrad, USSR dating back to the mid '60s. Laser-assisted micro- and nanotechnology is one of the first and most rapidly growing areas of research, development and production.

This conference was devoted to the wide spectrum of laser micro- and nanoprocessing from physical fundamentals of different processes and their experimental demonstration to industrial setups and their realization. Topics covered by FLAMN-07 include theoretical and experimental aspects of lasermatter interaction applied to laser micro- and nanotechnology.

Sessions of FLAMN-07 were visited by over 300 participants including 150 speakers, with approximately 75 of them from abroad (Belarus, Canada, Czech Republic, France, Germany, Italy, Japan, Korea, Latvia, Lithuania, UK, Ukraine, USA, Uzbekistan,). Approximately 140 papers were presented including 71 oral and 70 poster presentations. This volume contains 27 selected papers.

For the convenience of the reader all papers in this volume are arranged by three sections:

Section 1: Laser Physics and Technology of Material Sciences

Section 2: Laser-assisted Diagnostics and Spectroscopy

Section 3: Ultrashort Laser Pulses Interaction with Matter and Application in Laser Micro- and Nanotechnology

The Program Committee expresses its gratitude to all the institutions and persons who contributed to organizing, supporting, and holding the conference.

My special thanks are owed to the Scientific Secretary of the FLAMN-07, Dr. V. A. Parfenov, for his efforts to bring this volume to reality. 
Personal thanks to the FLAMN-07 Cooperating and Sponsoring organizations:

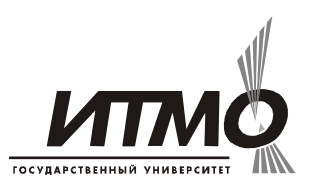

State University

of Information Technologies, Mechanics and Optics

(Russia)

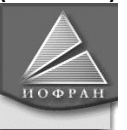

General Physics Institute of Russian Academy of Sciences, Moscow

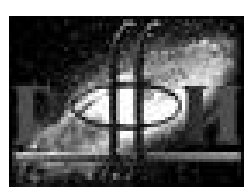

RFBR - Russian Foundation EOARD - European Office of for Basic Research

Aerospace Research and

Development (UK)

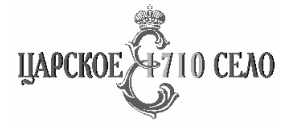

State Museum Preserve

"Tsarskoye Selo"

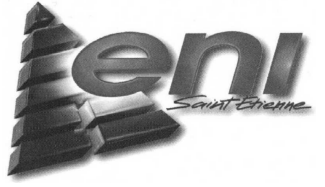

Ecole Nationale d'Ingeieurs de Saint-Etienne (France)

Vadim P. Veiko 